of low calorific value suitable for use with gas turbines. A number of plants might profitably operate on the same site, turning out fuels, chemical feedstocks and energy, and depending mutually on the by-products of each process.

The government's biggest commitment to energy research at the moment is, of course, in the area of nuclear power. In a written reply to a House of Commons question on the amount of investment in research into sources of energy alternative to oil Mr Peter Emery, Under Secretary of State for Energy, said that the United Kingdom Atomio Energy Authority is spending $£ 42.5$ million in the current year on research and development of nuclear fission reactors. The major part of this effort is devoted to the prototype fast reactor, which is expected to achieve "a significant level of power output" early this year.

The Central Electricity Generating Board is also carrying out research in the nuclear power field and Britain has an interest in nuclear fission research as an EEC partner. Another European energy venture, is a rescarch programme on hydrogen from water and on solar energy, estimated to have cost the community a total of $\mathfrak{£ 0 . 9}$ million in 1973 .

\section{Spies in Canada's research council}

from David Spurgeon, Ottawa

Many Camadians, including scientists and Members of Parliament, were startled in January by the allegation containcd in a television broadcast that their country's National Research Council (NRC) has for muiny years been serving as a cover for secret intelligence gathering.

Although the NRC unit involved-the Communications Branch-has bcen in existence since 1940, few Ottawa officials seemed to be aware of its existence or its mission. The director-general of information services in the Department of National Defence-a brigadier-general who has served with the department for some 30 years--told an inquirer that before the television program he had never heard of it.

Those who do know of its mission have been sworn to secrecy. Its director, N. K. O'Neill, refused to give a reporter information on its budget and staff, or indced to comment on anything concerning it. When asked to whom he reported, he replicd that he had been spending all that morning trying to find out. Questioners secking information from the NRC were directed to the Prime Minister's office (where a spokeman simply quoted from Mr Trudeau's comments on
January 11 in the House of Commons. The Prime Minister acknowledged that. Canada "has always collected what information was available to it in its territory", but said it had never to his knowledge "engaged in any cspionage abroad in the sense that we have not been looking for information in an undercover way in any other country". And he would not eonfirm the allegations made in the television program.

The program, aired by the Canadian Broadcasting Corporation (a Crown corporation funded by the federal government), claimed the NRC branch works hand-in-hand with the United States Central Intelligence Agency through the CIA's representative at the United Statcs embassy in Ottawa.

It monitors and records radio iraffic received through listening posts in the Aretic and elscwhere, and analyzes this and other intelligence gathered by the Royal Canadian Mounted Police and the armed forces. Encoded messages sent. from foreign embassies in the Canadian capital arc also monitored. The results of this work are shared with allies such as the United States and Britain.

Regardless of the accuracy of the details, it is apparent that the NRC's Communications Branch is in fact ongaged in highly secret work of a nature more usually associated with defence or security agencies than with national research laboratories. Inquiries reveal that: the branch came into existence during the second world war, when the NRC scemed the obvious place to go for help because of its scientists' expertise and contacts.

What seems strange is that the work was not moved after the war, either to the Defence Department or the newlyformed Defence Research Board. One reason secms to be that NIC simply provided too good a cover, and since moving the branch would only draw attention to it, those responsible felt it best to leave it where it was. It also scems strange that the matter has never before been raised publicly, because the branch is situated in its own building surrounded by a high wirc fence in plain view in southwest Ottawa (albeit far removed from other NRC buildings), and is listed in the government telephone directory.

Now that the branch has surfaced, its work is clearly an embarrassment to the NRC. Those in a position to know say attempts have been made by NRC for years to get rid of it. They also say NRC has contributed nothing to its policy, and that the president and council know little or nothing about it.

The importance of the affair for $\mathrm{Ca}$ nadian scientists is the effect it could have abroad on the image of the country's national laboratories. The NRC has been one of Canada's chief instruments of international science policy and its representative on many international scientific agencies. To be tarred with the CIA's brush will not help its reputation.

There are national implications too. As Douglas Fisher, former Member of Parliament and newspaper columnist put it in the Toronto Sun: "Highly placed people noting Watergate's excesses, get concerned. Could the Communications Branch, NRC, get out of band? . it's expenditures and work are never openly questioned or examined".

The questions raised by the television program may, however, lead to changes. David Lewis, leader of the New Democratic Party, which has hold the balance of power in the minority government, asked in the Commons: "In view of the fact that the NRC obviously is not the appropriate agency for such an operation ... may I ask the Prime Minister whether the government would consider taking (it) out ... a and placing it in a more appropriate department. . . ?" To which Mr Trudcau replied that he would consider the suggestion.

\section{Are PWRS good for Britain?}

\section{John Hall}

Wiт.н the British government hotly tipped to fall, and fall soon, for the attractions of a United States light water nuclear reactor in an attempt to stave off a threatened energy gap, there has bcen a lot of fast talking in London about the pros and cons of available nuclear options. Both Sir Arnold Weinstock of GEC and Lord Aldington, Chairman of the National Nuclear Corporations, have owned that they favour the American pressurised water reactor (PWR) as the best option for sccuring chcap power in the 1980s. Their evidence for this preference has not been reccived as gospel truth, cither by the House of Commons Select Committee to which it was presented, or by interestcd parties which included the Institution of Professional Civil Servants (IPCS) and the Trades Union Congress (TUC).

The energy resources sub-committee of the Select Committee on Science and Technology started hearings on the choice of reactor after information leaked from the Central Elcctricity Generating Board (CEGB) last autumn to the effect that its chairman, Mr. Arthur Hawkins, had a strong preference for the United States equipment as a quick and cheap answer to Britain's short term power problems. The current programme of advanced gas colled reactors is at least $£ 500$ million over budget, is running late by up to six years and is, according to Mr. Hawkins, a catastrophe which should not be repeated. 